Japan. J. Med. Sci. Biol., 39, 105-118, 1986.

\title{
PROPOSAL OF STANDARDIZED METHODS AND REFERENCE FOR ASSAYING RECOMBINANT HUMAN TUMOR NECROSIS FACTOR
}

\author{
Shudo YAMAZAKI, Eiko ONISHI, Kazue ENAMI, Katsuro NATORI, \\ Masayoshi KOHASE, Hajime SAKAMOTO ${ }^{1}$, Masatoshi TANOUCHI ${ }^{1}$ \\ and Hiroshi HAYASHI ${ }^{1}$
}

Central Virus Diagnostic Laboratory, National Institute of Health, 4-7-1, Gakuen, Musashimurayama-shi, Tokyo 190-12, and ${ }^{1}$ Technical Research Laboratory, Asahi Chemical Industry Co., Ltd., 2-1, Samejima, Fuji-shi, Shizuoka 416, Japan

(Received May 16, 1986. Accepted July 14, 1986)

SUMMARY: Two assay methods for recombinant human tumor necrosis factor (rH-TNF) were developed, one a biological L-cell assay and the other an enzyme-linked immunosorbent assay. The accuracy and reproducibility of each and the correlation between the two were studied. As a result of this investigation, the two assay methods were found appropriate for standardization of rH-TNF. A freeze-dried reference was prepared, and examination of its potency and stability showed it to be suitable for use as a reference standard for rH-TNF assays.

\section{INTRODUC'TION}

Tumor necrosis factor (TNF) was first discovered in mouse serum after iv injection of bacterial endotoxin into mice primed with Bacillus Calmette Guerin (1). Recently the gene-encoding human TNF has been cloned and expressed in Escherichia coli in several laboratories (2-6), resulting in wide availability of recombinant human TNF (rH-TNF), and world-wide interest in its clinical application has developed due to its in vivo antitumor activity $(7,8)$ and in vitro cytotoxic activity against various tumor cell lines (8). It has therefore become important to provide a basis for comparison of the materials used among different laboratories and the activity of the preparations intended for clinical application. This has been done for interferons by the establishment of standard assay methods,

山崎修道 · 大西英子 - 榎並和枝 - 名取克郎 - 小長谷昌功 (国立予防衛生研究所ウイルス 中央検查部)

阪本 肇・田中正敏・林 紘 (旭化成工業株式会社技術研究所 富士市鮫島 2-1) 
reference standard preparations, and an international unit of interferon potency under the leadership of the World Health Organization (9).

In our study, we considered various possible assay methods for rH-TNF and developed two, which have been found to be accurate and reproducible. One is a biological L-cell assay by which the cytotoxic activity of rH-TNF against L-M cells is measured. The other is an enzyme-linked immunosorbent assay (ELISA) using monoclonal antibodies by which the immunological activity of rH-TNF is measured. We prepared and then determined the potency of a freeze-dried reference preparation (Lot J-PS5K01), a candidate which may be used in the standardization of the unitage of rH-TNF.

\section{MATERIALS AND METHODS}

Chemicals: Fetal calf serum (FCS) was purchased from Filtron Inc. (Victoria, Australia); Trypsin (1:250) from Difco Laboratories (Detroit, MI); glutaraldehyde (25\%) from Nakarai Chemicals Ltd. (Tokyo); methylenblue from Merck Co. (Darmstadt, Germany); polyethylene glycol from Sigma Chemicals Co. (St. Louis, MO); peroxidase-conjugated anti-mouse immunoglobulin from Cappel Laboratories Inc. (Malvern, England); pepsin from Cooper Biomedicals Inc. (Malvern, PA); sephacryl S-300 from Pharmacia Fine Chemicals AB. (Uppsala, Sweden); 2mercaptoethylamine from Nakarai Chemicals Ltd. (Tokyo); horseradish peroxidase (grade I.C.) from Toyobo Ltd. (Tokyo); N-hydroxysuccinimide ester of N-(4carboxycyclohexylmethyl) maleimide from Zieben Chemicals Co. (Tokyo); Triton X-100 from Bio-Rad Laboratories (Richmond, VA); O-phenylendiamine (free base) from Sigma Chemical Co. (St. Louis, MO); and gelatin from Nippi Co. (Tokyo).

$r H-T N F$ : rH-TNF produced in bacteria was purified to give a single band (molecular weight 17,000 daltons) on SDS-PAGE (sodium dodecyl sulfate - 7.5\% polyacrylamide gel electrophoresis) according to the method described by Hayashi et al. (10) by Asahi Chemical Industry Co. Ltd. The specific activity of the purified rH-TNF was $2.3 \times 10^{6} \mathrm{U} / \mathrm{mg}$ protein with the unitage described in this article.

Target cells: The target cells were L-M cells (American Type Culture Collection, CCL 1.2). These cells were subcultured in Eagle's Minimum Essential Medium (MEM) containing 5\% fetal calf serum (FCS) and the antibiotics (100 $\mathrm{\mu g} / \mathrm{ml}$ streptomycin and $100 \mathrm{units} / \mathrm{ml}$ penicillin) in plastic dishes $(100 \mathrm{~mm}$ in diameter, Corning, NY) at $37 \mathrm{C}$. For the L-cell assay, the cells with a density of 2-5 $\times 10^{6}$ cells/dish of the logarithmic phase were used.

$L$-cell assay procedure: The rH-TNF samples were pre-diluted with MEM containing $1 \%$ FCS and the antibiotics to $4-200 \mathrm{U} / \mathrm{ml}$. Twofold serial dilutions were made with this medium in the wells of a 96 -well microplate $(0.1 \mathrm{ml} /$ well, Linbro, Flow Laboratories, VA). 
L-M cells in the logarithmic phase (see Target cells) were treated with $0.05 \%$ trypsin and $0.01 \%$ ethylenediaminetetraacetic acid in phosphate buffered saline (PBS), and then trypsin was removed by centrifugation. The cells were resuspended with MEM containing 1\% FCS and the antibiotics, and the cells were counted. To each well of the microplate, $0.1 \mathrm{ml}$ of the cell suspension adjusted to $10^{5} \mathrm{cells} / \mathrm{ml} \pm 5 \%$ was added and the plate was incubated at $37.0 \pm 0.2 \mathrm{C}$ for $48 \pm$ $1 \mathrm{hr}$ under $5 \% \mathrm{CO}_{2}$ /air and $100 \%$ humidity.

After incubation, $0.02 \mathrm{ml}$ of a $25 \%$ glutaraldehyde solution was added to each well to fix the surviving cells for $15 \mathrm{~min}$. After washing and removing the dead cells, the fixed cells were stained with $0.1 \mathrm{ml}$ of a $0.05 \%$ methyleneblue solution (15 min). Excess methyleneblue was washed off, and the plate was dried. For extraction of methyleneblue, $0.2 \mathrm{ml}$ of $0.33 \mathrm{~N} \mathrm{HCl}$ was added to each well, and the plate was agitated with a mixer. The absorbance at $665 \mathrm{~nm}$ was measured.

Calculation of titer in L-cell assay: The titer $(\mathrm{U} / \mathrm{ml})$ of the sample was defined as the reciprocal of the dilution resulting in $50 \%$ cell survival. The absorbance of control wells to which no rH-TNF had been added was defined as that of $100 \%$ cell survival. The reciprocal of the dilution of the sample corresponding to half of this absorbance (50\% cell survival) was determined with an on-line computer. A laboratory reference was simultaneously assayed on each plate and the measured titers of the reference were used to correct titers of the samples on the same plate.

Monoclonal antibodies: Monoclonal antibodies to $\mathrm{rH}-\mathrm{TNF}$ were prepared by Asahi Chemical Industry Co., Ltd. Briefly, spleen cells from rH-TNF-immunized $\mathrm{BALB} / \mathrm{c}$ mice and myeloma cells (P3/X63-Ag8U1) were fused with polyethylene glycol. Following HAT (hypoxanthine, aminopterin and thymidine) selection, the hybridoma cells were cloned and tested for production of anti-rH-INF by an ELISA with immobilized rH-TNF and peroxidase-conjugated anti-mouse-immunoglobulin. The hybridomas were further cloned by limiting dilution to obtain six different cell lines. Each monoclonal antibody was prepared from ascitic fluid. The ascitic fluid was clarified by centrifugation, and the monoclonal antibody was purified by ammonium sulfate precipitation. Three of the six purified monoclonal antibodies neutralized the rH-TNF cytotoxic activity. Two of these were selected for ELISA; they were designated as II2F3 and II7C2 (11).

First and second antibodies: The purified monoclonal antibody III2F3 was dialyzed against $20 \mathrm{mM}$ phosphate buffer, $\mathrm{pH} 8.0$, for use as the first antibody to trap rH-TNF. The purified monoclonal antibody II7C2 was digested with pepsin $(12,13)$ and applied to a Sephacryl S-300 column equilibrated with PBS. The main fraction was collected as $\mathrm{F}\left(\mathrm{ab}^{\prime}\right)_{2}$ fragment and reduced with 2-mercaptoethylamine to obtain Fab' fragment. The Fab' fragment and horseradish peroxidase were conjugated with $\mathrm{N}$-hydroxysuccinimide ester of N-(4-carboxycyclohexylmethyl) maleimide (14) for use as the second antibody.

ELISA procedure: The ELISA was performed with the first and second monoclonal antibodies against $r H-T N F$ and peroxidase. The first antibody (III2F3) was immobilized in the wells of a 96-well microplate (Immulon 2, Dynatech Lab., 
VA). After removal of excess antibody by washing with $0.2 \%$ Triton X-100 in PBS, the $\mathrm{rH}-\mathrm{TNF}$ test samples and the reference pre-diluted with $1 \mathrm{mg} / \mathrm{ml}$ gelatin in PBS to 10-100 U/ml were added to the wells. In $3 \mathrm{hr}$ at $25 \mathrm{C}$, each well was washed with $0.2 \%$ Triton X-100 in PBS. The second antibody was then added to the wells. In $90 \mathrm{~min}$ at $25 \mathrm{C}$, a substrate solution $(30 \mathrm{mg}$ of orthopheylenediamine and $7 \mu \mathrm{l}$ of hydrogen peroxide solution in $20 \mathrm{ml}$ of $0.1 \mathrm{M}$ citrate-phosphate buffer, $\mathrm{pH}$ 5.2) was added, and the plate was incubated for $15 \mathrm{~min}$ at room temperature. The reaction product was measured at $492 \mathrm{~nm}$ with an ELISA reader (11).

Preparation of $r H-T N F$ references: Two types of $\mathrm{rH}-\mathrm{TNF}$ reference preparations were prepared by Asahi Chemical Industry Co., Ltd.; a frozen reference preparation (lot ST-J) consisting of a purified $\mathrm{rH}-\mathrm{TNF}$ solution containing $1 \mathrm{mg} / \mathrm{ml}$ gelatin as a stabilizing agent and a freeze-dried reference preparation (Lot $\mathrm{J}$ PS5K01) containing purified $\mathrm{rH}-\mathrm{TNF}$ and $10 \mathrm{mg} / \mathrm{vial}$ human serum albumin. The frozen reference preparation was dispensed into plastic tubes and stored at $-70 \mathrm{C}$ until used. For the freeze-dried reference preparation, a purified $\mathrm{rH}-\mathrm{TNF}$ solution containing human serum albumin was exactly dispensed in $0.5-\mathrm{ml}$ portions into glass vials, which were then placed in the pre-cooled freeze-drying chamber, freezedried, backfilled with nitrogen and sealed with rubber stoppers and flip-off caps. The freeze-dried reference preparation was stored at $-20 \mathrm{C}$ for present and future use. Just before use, $1.0 \mathrm{ml}$ of distilled water was added to each vial to obtain a solution.

\section{RESULTS}

\section{Growth Curve and Sensitivity of $L-M$ Cells}

The growth curve and the sensitivity of L-M cells are shown in Fig. 1. The growth curve shows a one-day lag-time (day 0-1), logarithmic growth with a celldoubling time of $14.8 \mathrm{hr}$ (day 1-6), and a subsequent decline in the growth rate (day 6-8). Since the sensitivity of L-M cells against $\mathrm{rH}-\mathrm{TNF}$ was found to be relatively stable on day 2-4, L-M cells from this period of the logarithmic phase were used as the target cells as described in Materials and Methods.

\section{Factors Affecting Sensitivity of L-M Cells in L-cell Assay}

Examinations to determine standard conditions for L-cell assay showed three factors to be especially important. These are the inoculation cell density (Fig. 2), the incubation temperature (Fig. 3) and the incubation period (Fig. 4). The inoculation cell density in the standard method $\left(10^{4}\right.$ cells/well) was determined to obtain appropriate absorbance of the control wells. The slope of the curve in Fig. 3 increases at $38.0 \mathrm{C}$ or higher, which means that a small change in the incubation 


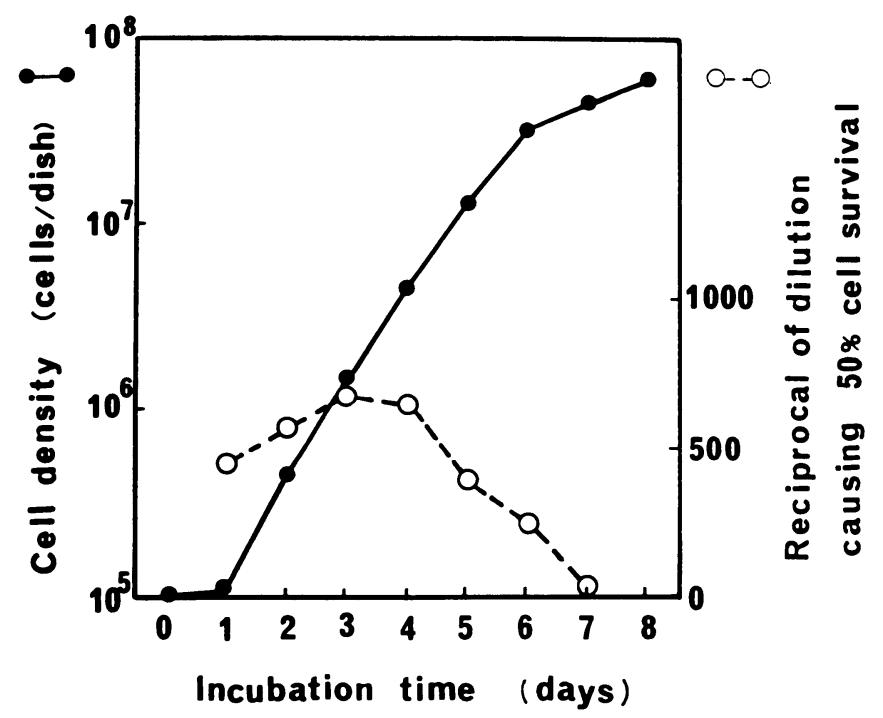

Fig. 1. Growth curve and sensitivity of L-M cells. L-M cells were inoculated in plastic tissue culture dishes ( $100 \mathrm{~mm}$ in diameter) at a density of $10^{5}$ cells/dish at day 0 , and incubated at $37 \mathrm{C}$ in $\mathrm{CO}_{2} /$ air. The cells were harvested, counted and used for assaying rH-TNF sample on days 1-8 by the L-cell assay method described in Materials and Methods.

temperature gives a considerable variation in assay results. Therefore, the incubation temperature $(37.0 \mathrm{C})$ was fixed to minimize the variation and is considered to be the usual temperature for cell cultures.

To obtain reproducible assay results, the limits of these factors were also set so that the inoculation cell density would be in the range of $10^{4}$ cells/well $\pm 5 \%$ and that L-M cells for the assay would be incubated in a precise temperature-controlled incubator at $37.0 \pm 0.2 \mathrm{C}$ for $48 \pm 1 \mathrm{hr}$.

A typical sigmoid dose-effect curve which was obtained for an rH-TNF sample by present L-cell assay under these conditions is shown in Fig. 5 .

Determination of Titer of Frozen Reference by L-cell Assay

The reference preparation (lot ST-J) was titrated by repeated L-cell assays. The results of 27 triplicate assays on eight different occasions were: average titer $=8,212 \mathrm{U} / \mathrm{ml}$, coefficient of variation $(\mathrm{CV})=17.4 \%$. The titer of this frozen reference preparation was therefore assigned a value of $8,200 \mathrm{U} / \mathrm{ml}$. 


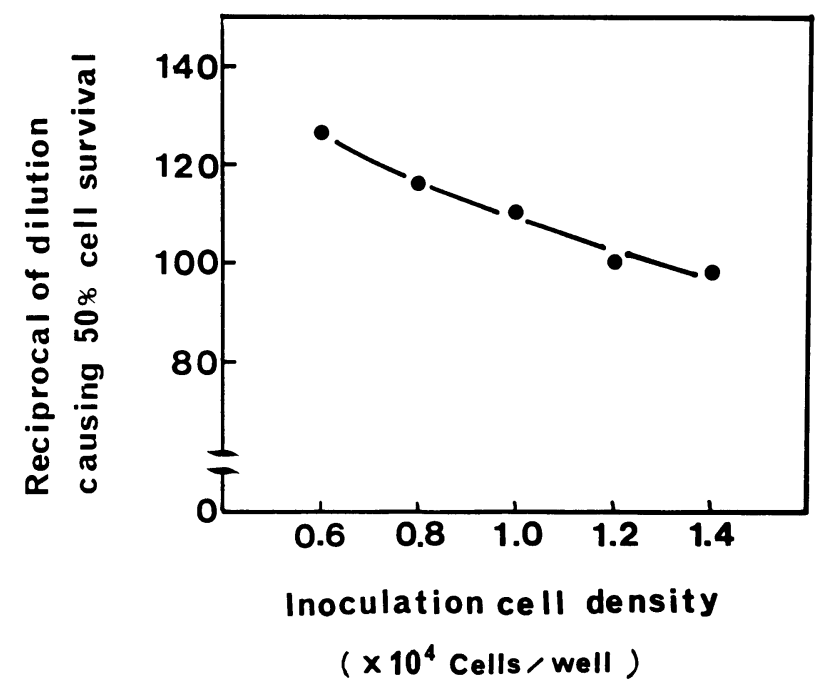

Fig. 2. Inoculation cell density and sensitivity of L-M cells. The inoculation cell density was varied, and the sensitivity of L-M cells was measured by the L-cell assay method using an rH-TNF sample.

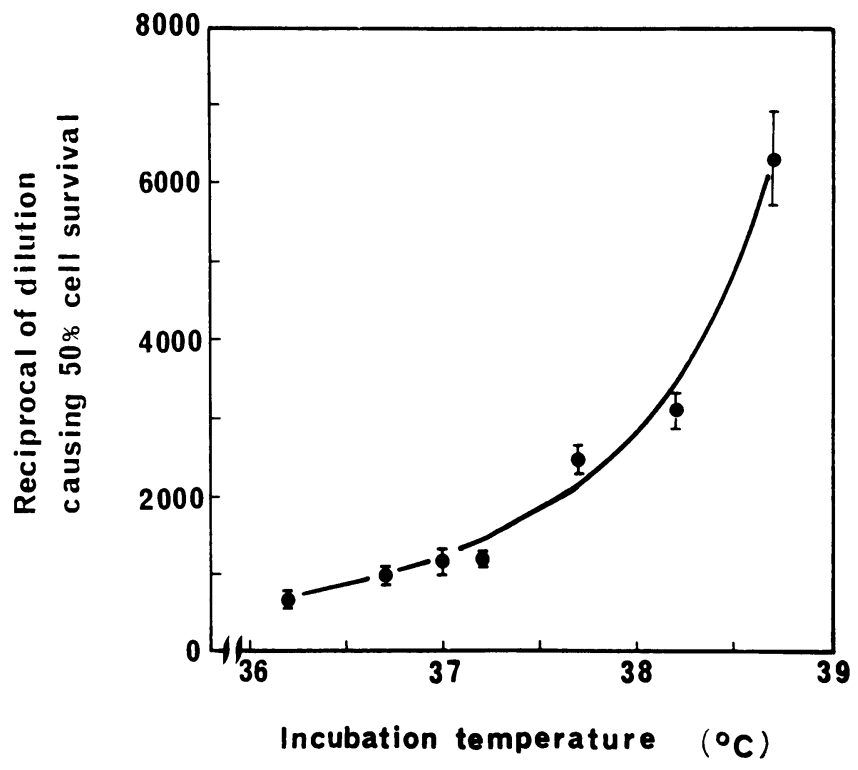

Fig. 3. Incubation temperature and sensitivity of L-M cells. An rH-TNF sample was assayed by L-cell assay at different incubation temperatures. Each point represents the mean \pm SEM of eight triplicate assay results. 


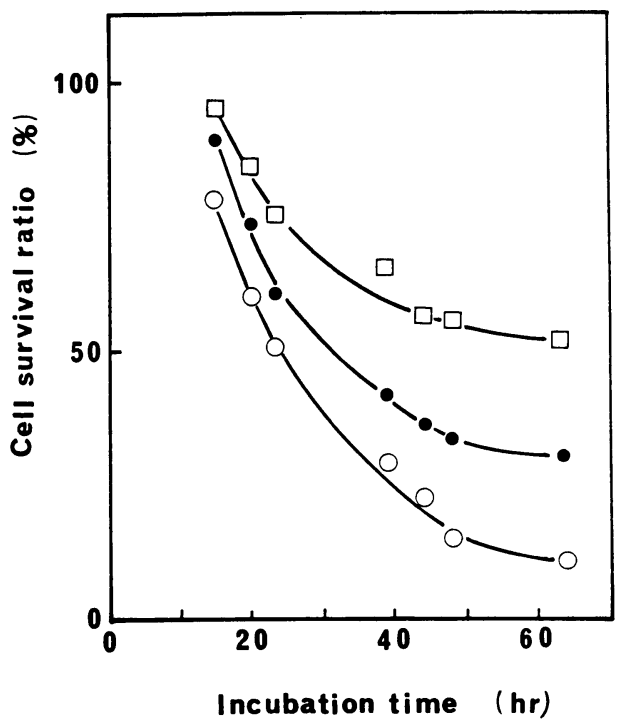

Fig. 4. Incubation period and viability of L-M cells. An rH-TNF sample was diluted $200(\bigcirc), 400(\bigcirc)$ and $800(\square)$ times and incubated with L-M cells by the L-cell assay method for different incubation periods.

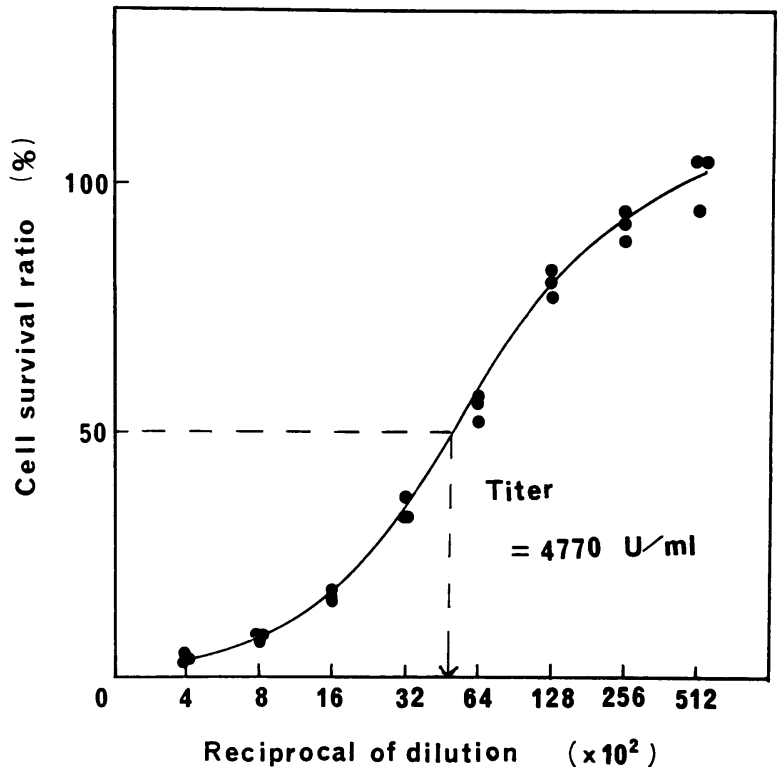

Fig. 5. A representative titration curve by L-cell assay. A rH-TNF sample was titrated in triplicate by L-cell assay. Each point represents the relative absorbance at $665 \mathrm{~nm}$ of each well of the microplate. The titer of this sample was $4,770 \mathrm{U} / \mathrm{ml}$. 


\section{Evaluation of the ELISA Method}

The present ELISA method, as described in Materials and Methods, was developed and adopted on the basis of the results of examinations on various conditions including incubation time and temperature. A typical standard curve obtained with this method is shown in Fig. 6. Linearity was observed between 10 and $100 \mathrm{U} / \mathrm{ml}$, and the coefficient of correlation was found to be higher than 0.99 .

\section{Correlation between ELISA and L-cell Assay}

The results of the ELISA and L-cell assay of $\mathrm{rH}-\mathrm{TNF}$ preparations in various degrees of purification and heat-denaturation are shown in Fig. 7. Identical values were obtained by the two methods, with a coefficient of correlation higher than 0.99 .

Determination of Potency of Freeze-dried Reference by L-cell Assay

The freeze-dried reference preparation (lot J-PS5K01) was titrated by L-cell assay in two laboratories. The results on eight different occasions at each

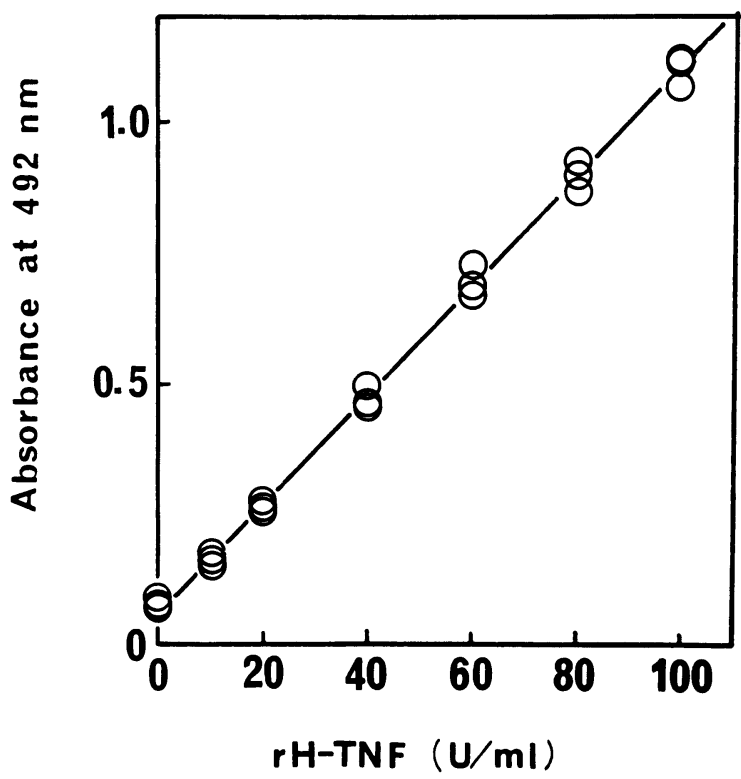

Fig. 6. Standard curve of $\mathrm{rH}-\mathrm{TNF}$ by ELISA. The reference preparation (lot ST-J) was diluted to $10-100 \mathrm{U} / \mathrm{ml}$ and measured in triplicate by the ELISA. The regression line is $y=0.0105 x+0.0572$, with a coefficient of correlation of 0.99831 . Each point represents the absorbance at 492 $\mathrm{nm}$ of each well of the microplate. 


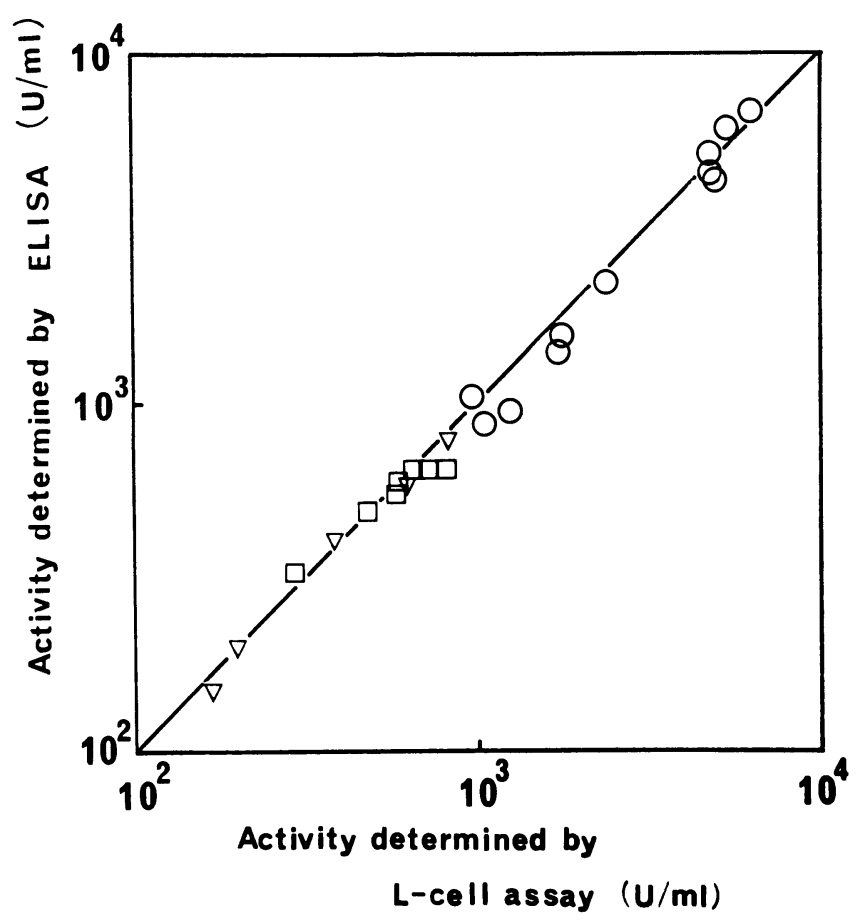

Fig. 7. Correlation between ELISA and L-cell assay. Various rH-TNF samples were measured by ELISA and L-cell assay using the reference preparation (lot ST-J) as standard. The samples were partially purified rH-TNF ( $\bigcirc$ ), and rH-TNF heat-treated at $68 \mathrm{C}$ for $5-40 \mathrm{~min}(\square)$ ) or at $72 \mathrm{C}$ for $10-40 \min (\nabla)$. The regression line is $\log \mathrm{y}=0.9916 \log \mathrm{x}-$ 0.0148 , with a coefficient of correlation of $0.9946(n=23)$.

laboratory are shown in Table I. The average corrected titer was about 11,000 U/vial in both laboratories.

Determination of Potency of Freeze-dried Reference by ELISA

The freeze-dried reference preparation was titrated also by ELISA in three laboratories. Representative results obtained in one of these are shown in Table II, with good reproducibility with 10 different vials and by three different researchers. The results including the above are summarized in Table III, which indicates good reproducibility among the laboratories, with an average value close to 11,000 U/vial obtained by L-cell assay. The potency of this freeze-dried reference preparation was therefore assigned $11,000 \mathrm{U} / \mathrm{vial}$. 
Table I. Titration of freeze-dried reference by L-cell assay

\begin{tabular}{|c|c|c|c|c|c|c|}
\hline \multirow{3}{*}{$\begin{array}{l}\text { Reference } \\
\text { laboratory }\end{array}$} & \multicolumn{4}{|c|}{ Observed titer } & \multirow{2}{*}{\multicolumn{2}{|c|}{$\frac{\text { Corrected titer }}{\text { J-PS5KO1 }}$}} \\
\hline & \multicolumn{2}{|c|}{ ST-J } & \multicolumn{2}{|c|}{ J-PS5KO1 } & & \\
\hline & $\mathrm{A}$ & $\mathrm{B}$ & $\mathrm{A}$ & $\mathrm{B}$ & $\mathrm{A}$ & B \\
\hline $\begin{array}{l}\text { Number of } \\
\text { assays }\end{array}$ & 24 & 24 & 48 & 48 & 48 & 48 \\
\hline $\begin{array}{l}\text { Average } \\
\left(\times 10^{3} \mathrm{U} / \mathrm{ml}\right)\end{array}$ & 8.72 & 8.54 & 11.83 & 11.64 & 11.27 & 11.24 \\
\hline CV (\%) & 14.5 & 14.5 & 14.4 & 14.2 & 13.1 & 10.8 \\
\hline
\end{tabular}

In two laboratories, repeated L-cell assays were performed to determine the potency of the freeze-dried reference preparation (lot J-PS5KO1). The frozen reference preparation (lot ST-J) with the assigned titer of $8,200 \mathrm{U} / \mathrm{ml}$ was also assayed simultaneously on each microplate and served as a standard for titer correction. Each microplate carried two (in laboratory A) or three (in laboratory B) lanes of the frozen reference preparation and four (in laboratory A) or six (in laboratory B) lanes of the freeze-dried reference preparation. Each titer was calculated from the two (in laboratory A) or three (in laboaratory B) lanes, and therefore each microplate gave one and two assay results for ST-J and J-PS5KO1, respectively. The assays were repeated with three microplates on eight different occasions in each laboratory. Corrections were made as follows: Corrected titer of J-PS5KO1 $(\mathrm{U} / \mathrm{ml})=$ (Observed titer of J-PS5KO1) $/($ Observed titer of ST-J) $\times 8,200$.

\section{Stability of Freeze-dried Reference}

The predictive multiple isothermal stability test (15) was performed to estimate the stability of the freeze-dried reference preparation. From the results of the test involving storage at $60-90 \mathrm{C}$ for up to 28 days, the reference preparation is estimated to have a residual activity higher than $99.9 \%$ after 10 year storage at -20 $\mathrm{C}$ or below. The confirmatory multiple isothermal stability test (15) is now being performed. Interim results indicate that no potency loss occurs in storage at room temperature for at least 2 months. 
Table II. Titration of freeze-dried reference by ELISA in laboratory A

\begin{tabular}{|c|c|c|c|c|}
\hline \multirow{3}{*}{ Vial No. } & \multicolumn{4}{|c|}{ Observed potency of J-PS5KO1 ( $\left.\times 10^{3} \mathrm{U} / \mathrm{ml} / \mathrm{vial}\right)$} \\
\hline & \multicolumn{3}{|c|}{ Researcher } & \multirow{2}{*}{ Average } \\
\hline & 0 & $\mathrm{E}$ & $\mathrm{K}$ & \\
\hline 1 & 11.29 & 11.34 & 11.66 & 11.43 \\
\hline 2 & 11.96 & 11.40 & 10.88 & 11,41 \\
\hline 3 & 11.27 & 11.26 & 11.08 & 11.20 \\
\hline 4 & 11.17 & 10.62 & 10.94 & 10.91 \\
\hline 5 & 11.34 & 10.38 & 10.82 & 10.85 \\
\hline 6 & 11.67 & 10.20 & 10.98 & 10.95 \\
\hline 7 & 11.85 & 10.84 & 11.24 & 11.31 \\
\hline 8 & 12.01 & 10.56 & 10.30 & 10.96 \\
\hline 9 & 11.63 & 10.38 & 10.34 & 10.78 \\
\hline 10 & 11.21 & 11.04 & 11.26 & 11.17 \\
\hline Number of assays & 10 & 10 & 10 & 10 \\
\hline Average potency & 11.54 & 10.80 & 10.95 & 11.10 \\
\hline $\mathrm{CV}(\%)$ & 2.8 & 4.1 & 3.8 & 2.1 \\
\hline
\end{tabular}

In laboratory $\mathrm{A}, 10$ vials of the freeze-dried reference preparation (lot $\mathrm{J}$ PS5KO1) were titrated by three researchers by the ELISA using the frozen reference preparation (lot ST-J) as standard. Each value in the table represents the mean of six wells in two plates or the average of these values. The average of 30 assays for 10 vials was $11,100 \mathrm{U} / \mathrm{ml} / \mathrm{vial}$ with $\mathrm{CV}$ of $4.5 \%$. 
Table III. Summary of results of the collaborative assay study of the freeze-dried rH-TNF reference preparation (J-PS5K01)

\begin{tabular}{llcc}
\hline \multicolumn{1}{c}{ Laboratory } & $\mathrm{A}$ & $\mathrm{B}$ & $\mathrm{C}$ \\
\hline $\begin{array}{l}\text { Number of vial } \\
\text { assayed }\end{array}$ & 10 & 20 & 10 \\
Number of assays & 30 & 50 & 30 \\
A verage $\left(\times 10^{3}\right.$ & 11.10 & 10.90 & 11.06 \\
U/ml/vial) & 4.5 & 5.2 & 4.1 \\
$\mathrm{CV}(\%)$ & &
\end{tabular}

In laboratories $\mathrm{B}$ and $\mathrm{C}$, the same measurements were performed as those described in the legend to Table II. The assay results by all three laboratories are summarized here, with the including the results of Table II. The average of assays for 40 vials was $11,010 \mathrm{U} / \mathrm{ml} / \mathrm{vial}$ with $\mathrm{CV}$ of $3.1 \%$.

\section{DISCUSSION}

rH-TNF has been titrated in various laboratories by in vitro bioassay methods (2-6). Bioassays can give a direct biological activity of the substance but are subject to a certain degree of variability. We determined the key factors affecting the sensitivity of the target cells (Figs. 2 to 4 ) and applied the strict control of these factors to develop and establish the present method. As shown in Table I, this method yielded virtually the same potencies in two different laboratories, with good reproducibility for bioassay $(\mathrm{CV}=10-13 \%)$. On the other hand, its proper performance involves some rather difficult requirements, including aseptic conditions, considerable period (at least $48 \mathrm{hr}$ ), and appropriate equipments as well as great effort to maintain strict control of the assay conditions.

The sensitivity, accuracy and reproducibility of ELISA, as a possible alternative assay method, were therefore examined. The sensitivity of ELISA was approximately the same as that of the L-cell assay (sensitivity $=10 \mathrm{U} / \mathrm{ml}$ or about $5 \mathrm{ng} / \mathrm{ml}$ ). The potencies obtained by ELISA in three laboratories agreed closely with that obtained by L-cell assay, indicating a high accuracy. Very low $\mathrm{CV}$ values $(<5 \%)$ were observed even when assays were performed in different laboratories by different researchers on different days, reflecting good re- 
producibility. ELISA is simpler in procedure and requires only one day. It is thus particularly advantageous when a large number of assays are required.

If an immunochemical method such as the ELISA is to be applied to titrate physiologically active substances, it is essential to confirm that the method can distinguish inactive molecules from intact active molecules. The close correlation between the results of ELISA and L-cell assay for partially heat-denatured $\mathrm{rH}$ TNF samples (Fig. 7) confirmed that the monoclonal antibodies used for ELISA can distinguish heat-inactivated $\mathrm{rH}-\mathrm{TNF}$ from active one. The monoclonal antibodies neutralized the biological activity of rH-TNF, which suggests that they recognize the active site itself or a region very nearby. It thus appears that the nonrecognition of molecules inactivated by conformational change around the active site may be attributed to the resulting inhibition of the binding by these neutralizing-type antibodies. For these reasons, we believe that ELISA is most appropriate as for quantitative determination of rH-TNF.

To standardize the unitage of physiologically active substances, appropriate reference standards must be established. Such a reference preparation must be stable, uniform in content, widely available and well characterized. The freezedried rH-TNF reference preparation (lot J-PS5K01) meets all these criteria. It is estimated to have almost unlimited stability at $-20 \mathrm{C}$ or below and to be stable at room temperature for a period sufficient for transportation. Very good uniformity ( $\mathrm{CV}=3.1 \%$ ) was observed with 40 vials, as shown in Table III. Availability is assured, as we prepared reference vials in a sufficient number to supply a number of laboratories for several years. Its potency was determined to be $11,000 \mathrm{U} / \mathrm{vial}$ by repeated assays ( $n=206$ in total) by the two methods. The rH-TNF used as the reference was purified to homogeneity and well characterized (10). We therefore believe this reference preparation to be appropriate as an $\mathrm{rH}-\mathrm{TNF}$ reference standard. 


\section{REFERENCES}

1. Carswell, E. A., Old, L. J., Kassel, R. L., Green, S., Fiore, N. and Williamson, B. (1975): Proc. Natl. Acad. Sci. USA,72, 3666-3670.

2. Shirai, T., Yamaguchi, H., Ito, H., Todd, C. W. and Wallace, R. B. (1985): Nature, 313, 803-806.

3. Soumura, Y., Nakano, S., Abe, M., Nakada, K., Yoshida, H., Kashimoto, S., Kuwazima, J., Furuta, R., Yamada, M. and Tanaka, N. (1985): Japan. J. Cancer Chemother., 12, 160-162 (text in Japanese).

4. Pennica, D., Nedwin, G. E., Hayflick, J. S., Seeburg, P. H., Derynck, R., Palladino, M. A., Kohr, W. J., Aggarwal, B. B. and Goeddel, D. V. (1984): Nature 312, 712-729.

5. Wang, A. M., Creasey, A. A., Ladner, M. B., Lin, L. S., Strickler, J., van Arsdell, J. N., Yamamoto, R. and Mark, D. F. (1985): Science, 228, 149-154.

6. Marmenout, A., Fransen, L., Tavernier, J., van der Heyden, J., Tizard, R., Kawashima, E., Shaw, A., Johnson, M-J., Semon, D., Müller, R., Ruysschaert, M-R., van Vliet, A. and Fiers, W. (1985): Eur. J. Biochem., 152, 515-522.

7. Enomoto, H., Yoshida, J., Kageyama, N., Ueda, R., Kato, T. and Ota, K. (1986) : Japan. J. Cancer Chemother., 13, 1953-1961 (text in Japanese).

8. Hayashi, H., Oishi, J., Hori, K. and Maeda, N. (1985): In Recent Advances in Chemotherapy, J. Ishigami [ed.], p.818-819. Proceeding of the 14th International Chemotherapy, University of Tokyo Press, Tokyo.

9. World Health Organization (1983): WHO Technical Report Series, No. 687, 1-184.

10. Hayashi, H., Kiyota, T., Kajiwara, J., Otsuka, Y., Inada, T. and Yoshida, N. (1985): In Recent Advances in Chemotherapy, J. Ishigami [ed.], 816-817. Proceeding of the 14th International Chemotherapy, Unviersity of Tokyo Press, Tokyo.

11. Hayashi, H., Kiyota, T., Sakamoto, H. and Seto, M. (1985): In Recent Advances in Chemotherapy, J. Ishigami [ed.], 820-821. Proceeding of the 14th International Chemotherapy, University of Tokyo Press, Tokyo.

12. Hamaguchi, Y., Yoshitake, S., Ishikawa, E., Endo, Y. and Ohtaki, S. (1979): J. Biochem., 85, 1289-1300.

13. Kato, K., Hamaguchi, Y., Fukui, H. and Ishikawa, E. (1975): FEBS Lett., 56, 370-372.

14. Yoshitake, S., Imagawa, M., Ishikawa, E., Niitsu, Y., Urushizaki, I., Nishiura, M., Kanazawa, R., Kurosaki, H., Tachibana, S., Nakazawa, N. and Ogawa, H. (1982): J. Biochem., 92, 1413-1424.

15. Jameson, P., Greiff, D. and Grossberg, S. E. (1979): Cryobiology, 16, 301-314. 